\title{
Separation of Cobalt and Nickel from Sulfate Solutions
}

\author{
Lifang Kuang ${ }^{1, a}$, Junyue Tan ${ }^{1, b}$ and Kui Liu ${ }^{1, c^{*}}$ \\ ${ }^{1}$ School of Chemistry and Pharmaceutical Science, Guangxi Normal University, Guilin 541004, \\ China \\ ahua163@126.com, wwmm@126.com, 'Iku009@163.com
}

Keywords: cobalt sulfate; nickel sulfate; sodium hypochlorite; separation

Abstract. Separation of cobalt and nickel from sulfate solutions was studied, using the sodium hypochlorite solution as the oxidant of $\mathrm{Co}^{2+}$. The cobalt removal rate reached $98 \%$ while $\mathrm{Ni}^{2+}$ was hardly oxidized at $80^{\circ} \mathrm{C}, 1 \mathrm{~h}, \mathrm{pH} 2.3$ and $\mathrm{Co}^{2+} / \mathrm{ClO}^{-}$molar ratio of $1: 15$. Solution $\mathrm{pH}$ and the amount of $\mathrm{ClO}^{-}$had more significant influences on oxidation of $\mathrm{Co}^{2+}$ and $\mathrm{Ni}^{2+}$. Increasing temperature could improve the filtration performance of the solid product. The $\mathrm{Co}^{2+}$ oxidation product was $\mathrm{CoOOH}$. Adding the sodium hypochlorite solution in more than one times could inhibit the $\mathrm{Ni}^{2+}$ oxidation to $\mathrm{NiOOH}$.

\section{Introduction}

Cobalt and nickel often coexist in cobalt or nickel ores and are leached together into the liquors during acid leaching of cobalt or nickel ores. In the leach liquors, cobalt and nickel are difficult to separate because of their similar physical and chemical properties[1-3]. Solvent extraction is the main technology for separating nickel and cobalt [4-6], but needs many stages of extraction procedures and is easy to be influenced by the $\mathrm{Mg}^{2+}$ ions in the solutions.

Cobalt and nickel can react with some oxidants and are oxidized to trivalent compounds of cobalt and nickel. In this study, sodium hypochlorite was selected as the oxidant. The possibility of separation of cobalt and nickel using sodium hypochlorite was investigated. The oxidation products of cobalt and nickel in sulfate solutions were studied. The results may be helpful for the separation of cobalt and nickel in sulfate solutions.

\section{Experimental}

Materials. The feed solution containing $\mathrm{Co}^{2+}$ and/or $\mathrm{Ni}^{2+}$ used in this study was prepared by dissolving cobalt sulfate, nickel sulfate (analytical grade) with distilled water, with $\mathrm{Ni}^{2+}$ and/or $\mathrm{Co}^{2+}$ concentrations of $5 \mathrm{~g} / \mathrm{L}$ and $0.4-2 \mathrm{~g} / \mathrm{L}$. The industrial sodium hypochlorite $(10 \%)$ solution was used directly. The solution $\mathrm{pH}$ was adjusted using the dilute sulfuric acid.

Methods. Leaching experiments were carried out in a 500ml Erlenmeyer flask. The feed solution and the sodium hypochlorite solution were placed in the Erlenmeyer flask. The Erlenmeyer flask was placed in a magnetic stirrer, heated to the desired temperature, and then leached for a set time at 450rpm. The slurry was filtered and the leach residues were washed with distilled water and dried for $4 \mathrm{~h}$ at $100^{\circ} \mathrm{C}$.

The solution $\mathrm{pH}$ was measured using a $\mathrm{pH}$ meter (PHS-3E, Shanghai INESA Scientific Instrument Co., Ltd., China). The filtrate was analyzed for nickel and cobalt by a Hitachi Z-5000 atomic absorption spectrometer. The amount of metal ion entering into solid products was the difference between mass of metal ion in the feed solution and in the filtrate. The removal rate of metal ion was calculated as the ratio of the amount of metal ion entering into solid products to that in the feed solution. Some solid products were analyzed using a D/max $2550 \mathrm{X}$-ray diffractometer (XRD) with $\mathrm{Cu} \mathrm{K} \alpha$ radiation between $10^{\circ}$ to $80^{\circ}(2 \theta)$. 


\section{Results and discussion}

Reaction of $\mathrm{Co}^{2+}$ and $\mathrm{ClO}^{-}$. The feed solution containing $0.4 \mathrm{~g} / \mathrm{L} \mathrm{Co}^{2+}$ was selected to react with the sodium hypochlorite (10\%) solution. The results are shown in Tables 1-4.

Table 1 Effect of solution $\mathrm{pH}$ on cobalt oxidation

$\left(20^{\circ} \mathrm{C}, 1 \mathrm{~h}, \mathrm{Co}^{2+} / \mathrm{ClO}^{-}\right.$molar ratio $\left.1: 13\right)$

\begin{tabular}{clc}
\hline Feed solution $\mathrm{pH}$ & \multicolumn{1}{c}{ Phenomena } & Cobalt removal rate $(\%)$ \\
\hline 5.7 & difficult to be filtered & 78.6 \\
4.4 & difficult to be filtered & 86.1 \\
2.6 & difficult to be filtered & 69.4 \\
1.1 & traces of products & 1.3
\end{tabular}

Table 1 shows that the cobalt removal rate increases with the increase of solution $\mathrm{pH}$, but the most solid products are extremely fine and difficult to be filtered.

Table 2 Effect of temperature on cobalt oxidation (feed solution $\mathrm{pH} 5.7,1 \mathrm{~h}, \mathrm{Co}^{2+} / \mathrm{ClO}^{-}$molar ratio $1: 13$ )

\begin{tabular}{ccc}
\hline Temperature $\left({ }^{\circ} \mathrm{C}\right)$ & Phenomena & Cobalt removal rate $(\%)$ \\
\hline 15 & difficult to be filtered & 88.4 \\
25 & difficult to be filtered & 84.5 \\
35 & easy to be filtered & 85.8 \\
55 & easy to be filtered & 86.4 \\
70 & easy to be filtered & 86.9 \\
\hline
\end{tabular}

Table 2 shows that the cobalt removal rate keeps at about $85 \%$ within the temperature range of $15-70^{\circ} \mathrm{C}$, but the oxidation products became easy to be filtered with the increase of temperature.

Table 3 Effect of reaction time on cobalt oxidation

\begin{tabular}{cc} 
(feed solution $\mathrm{pH} 5.7,15^{\circ} \mathrm{C}, \mathrm{Co}^{2+} / \mathrm{ClO}^{-}$molar ratio $\left.1: 13\right)$ \\
\hline Reaction time $(\mathrm{min})$ & Cobalt removal rate $(\%)$ \\
\hline 15 & 85.6 \\
30 & 85.2 \\
60 & 88.3
\end{tabular}

It can be seen from Table 3 that the cobalt removal rate increases with the increase of reaction time, but the increasing extent is low, indicating the cobalt oxidation is a rapid reaction.

The cobalt removal rate increased significantly with the decrease of $\mathrm{Co}^{2+} / \mathrm{ClO}^{-}$molar ratio, and reached about $95 \%$ and $98 \%$ at $\mathrm{Co}^{2+} / \mathrm{ClO}^{-}$molar ratios of $1: 11$ and $1: 21$, as seen in Table 4 . This indicates that increasing the amount of $\mathrm{ClO}^{-}$facilitates the $\mathrm{Co}^{2+}$ oxidation.

Table 4 Effect of $\mathrm{Co}^{2+} / \mathrm{ClO}^{-}$molar ratio on cobalt oxidation

\begin{tabular}{cc}
\multicolumn{2}{c}{ (feed solution $\left.\mathrm{pH} 5,80^{\circ} \mathrm{C}, 1 \mathrm{~h}\right)$} \\
\hline $\mathrm{Co}^{2+} / \mathrm{ClO}^{-}$molar ratio & Cobalt removal rate $(\%)$ \\
\hline $1: 3$ & 49.2 \\
$1: 6$ & 79.8 \\
$1: 11$ & 95.1 \\
$1: 21$ & 98.4 \\
$1: 31$ & 98.4 \\
\hline
\end{tabular}


Reaction of $\mathrm{ClO}^{-}$and solution containing $\mathrm{Co}^{2+}$ and $\mathrm{Ni}^{2+}$. The feed solution containing $2 \mathrm{~g} / \mathrm{L}$ $\mathrm{Co}^{2+}$ and $5 \mathrm{~g} / \mathrm{L} \mathrm{Ni}^{2+}$ was selected to react with sodium hypochlorite $(10 \%)$ solution. The results are shown in Table 5.

Table 5 Effect of solution $\mathrm{pH}$ on oxidation of cobalt and nickel $\left(80^{\circ} \mathrm{C}, 1 \mathrm{~h}, \mathrm{Co}^{2+} / \mathrm{ClO}^{-}\right.$molar ratio $\left.1: 1\right)$

\begin{tabular}{ccc}
\hline Feed solution $\mathrm{pH}$ & Cobalt removal rate $(\%)$ & Nickel removal rate $(\%)$ \\
\hline 2.7 & 18.5 & 0 \\
2.5 & 20.8 & 0 \\
2.3 & 23.2 & 0 \\
2.1 & 22.1 & 0 \\
1.9 & 24.4 & 0 \\
\hline
\end{tabular}

In the $\mathrm{pH}$ range of $1.9-2.7$, the nickel removal rate was essentially zero at $\mathrm{Co}^{2+} / \mathrm{ClO}^{-}$molar ratio of $1: 1$, but the cobalt removal rate was only about $20 \%$, as seen in Table 5. It was found in the experiments that the $\mathrm{Ni}^{2+}$ could react with $\mathrm{ClO}^{-}$if increasing the amount of $\mathrm{ClO}^{-}$or increasing feed solution $\mathrm{pH}$ to 3 or above, for example, the nickel removal rate reached about $5 \%$ when $\mathrm{Co}^{2+} / \mathrm{ClO}^{-}$ molar ratio was 1:3. In order to improve the cobalt removal rate and inhibit the oxidation of $\mathrm{Ni}^{2+}$, the following experiments were carried out at a decreased $\mathrm{Co}^{2+} / \mathrm{ClO}^{-}$molar ratio, but the sodium hypochlorite solution was added in more than one times. The results are shown in Table 6 and Fig.1.

Table 6 Effect of $\mathrm{Co}^{2+} / \mathrm{ClO}^{-}$molar ratio on oxidation of cobalt and nickel $\left(80^{\circ} \mathrm{C}, 1 \mathrm{~h}\right.$, feed solution $\left.\mathrm{pH} 2.3\right)$

\begin{tabular}{cccc}
\hline $\mathrm{Co}^{2+} / \mathrm{ClO}^{-}$molar ratio & $\begin{array}{l}\text { Adding manner of the } \\
\mathrm{ClO}^{-} \text {solution }\end{array}$ & Cobalt removal rate (\%) & Nickel removal rate (\%) \\
\hline $1: 3$ & adding in 5 times & 52.6 & 0 \\
$1: 6$ & adding in 6 times & 76.1 & 0 \\
$1: 9$ & adding in 9 times & 89.4 & 0 \\
$1: 15$ & adding in 12 times & 98.8 & 0 \\
\hline
\end{tabular}

When $\mathrm{Co}^{2+} / \mathrm{ClO}^{-}$molar ratio was 1:15 and the sodium hypochlorite solution was added in 12 times, the cobalt removal rate reached about $98 \%$, and the nickel removal rate was nearly zero. This indicates that the amount of $\mathrm{ClO}^{-}$can be increased to improve the cobalt removal rate, but the sodium hypochlorite solution should add in more than one times to control the $\mathrm{ClO}^{-}$amount for every time, and thus can inhibit the $\mathrm{Ni}^{2+}$ oxidation. XRD analysis of the solid product showed the oxidation product was $\mathrm{CoOOH}$, as seen in Fig.1. Therefore, the $\mathrm{Co}^{2+}$ oxidation by $\mathrm{ClO}^{-}$is as Eq.1:

$$
2 \mathrm{Co}^{2+}+\mathrm{ClO}^{-}+3 \mathrm{H}_{2} \mathrm{O}===2 \mathrm{CoOOH} \downarrow+\mathrm{Cl}^{-}+4 \mathrm{H}^{+}
$$

$\mathrm{As}^{2+}{ }^{2+}$ was not oxidized by $\mathrm{ClO}^{-}$, there was no $\mathrm{NiOOH}$ produced. Therefore, $\mathrm{Co}^{2+}$ and $\mathrm{Ni}^{2+}$ can be separated under this condition. 


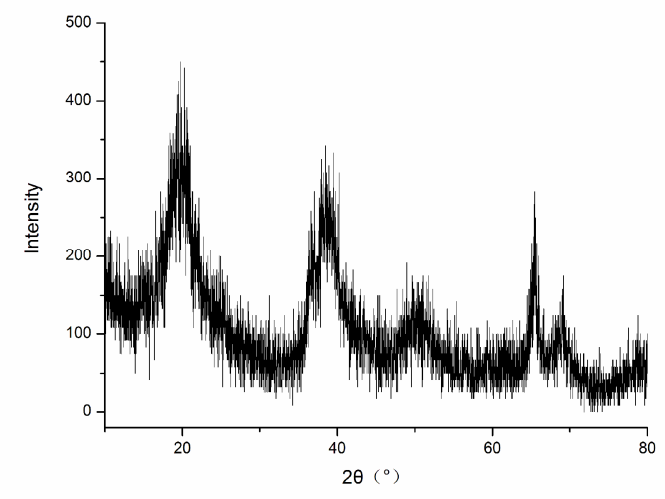

Fig. 1 XRD pattern of solid product of $\mathrm{Co}^{2+}$ oxidation $\left(\mathrm{Co}^{2+} / \mathrm{ClO}^{-}\right.$molar ratio of $1: 15$, adding in 12 times $)$

\section{Conclusions}

Cobalt and nickel could be separated in sulfate solution through the reaction with sodium hypochlorite solution at $80^{\circ} \mathrm{C}, 1 \mathrm{~h}, \mathrm{pH} 2.3$ and $\mathrm{Co}^{2+} / \mathrm{ClO}^{-}$molar ratio of $1: 15$. Increasing temperature did not increase the speed of $\mathrm{Co}^{2+}$ oxidation obviously, but improved the filtration performance of the solid product. Increasing feed solution $\mathrm{pH}$ and the amount of $\mathrm{ClO}^{-}$would increase the $\mathrm{Co}^{2+}$ removal rate, but resulted in the $\mathrm{Ni}^{2+}$ oxidation. The $\mathrm{Co}^{2+}$ oxidation product was $\mathrm{CoOOH}$. The adding amount of the sodium hypochlorite solution should be controlled for every time to inhibit the $\mathrm{Ni}^{2+}$ oxidation to $\mathrm{NiOOH}$.

\section{Acknowledgements}

This work is financially supported by National Nature Science Foundation of China (No. 51264003) and Natural Science Foundation of Guangxi Province (CN) (No. 2014GXNSFAA118325).

\section{References}

[1] R.G. McDonald and B.I. Whittington: Hydrometallurgy Vol.91 (2008), P.35.

[2] B.I.Whittington and D. Muir: Minerals Processing and Extractive Metallurgy Review Vol.21 (2000), p.527.

[3] S. Agatzini-Leonardou, I. G. Zafiratos: Hydrometallurgy Vol.74 (2004) , P.267.

[4] Y. Liu and M. Lee: Journal of the Korean Institute of Resources Recycling Vol. 22(2013), p.11

[5] B.R.Reddy and K.H.Park: Separation Science and Technology Vol. 42(2007), p.2067.

[6] N.A.Sayar, M. Filiz and A.A. Sayar: Hydrometallurgy Vol. 96(2009), p.148. 